Article

\title{
Polar Metallocenes
}

\author{
Haiwu Zhang ${ }^{1}$, B.Yu. Yavorsky ${ }^{1}$ and R.E. Cohen ${ }^{1,2, *(1)}$ \\ 1 Department of Earth and Environmental Sciences, Ludwig-Maximilians Universität München, Theresienstr, \\ 4180333 Munich, Germany; zhw3789@sina.com (H.Z.); bogdan.yavorskyy@o2online.de (B.Y.Y.) \\ 2 Extreme Materials Initiative, Geophysical Laboratory, Carnegie Institution for Science, Washington, \\ DC 20015, USA \\ * Correspondence: rcohen@carnegiescience.edu
}

Received: 24 December 2018; Accepted: 26 January 2019; Published: 29 January 2019

check for updates

\begin{abstract}
Crystalline polar metallocenes are potentially useful active materials as piezoelectrics, ferroelectrics, and multiferroics. Within density functional theory (DFT), we computed structural properties, energy differences for various phases, molecular configurations, and magnetic states, computed polarizations for different polar crystal structures, and computed dipole moments for the constituent molecules with a Wannier function analysis. Of the systems studied, $\mathrm{Mn}_{2}\left(\mathrm{C}_{9} \mathrm{H}_{9} \mathrm{~N}\right)_{2}$ is the most promising as a multiferroic material, since the ground state is both polar and ferromagnetic. We found that the predicted crystalline polarizations are $30-40 \%$ higher than the values that would be obtained from the dipole moments of the isolated constituent molecules, due to the local effects of the self-consistent internal electric field, indicating high polarizabilities.
\end{abstract}

Keywords: metallocenes; DFT; vdW interactions; polarization; materials design

\section{Introduction}

Metallocenes have manifold uses ranging from fire retardants, catalysts, and cancer pharmaceuticals [1-3]. Almost all applications of metallocenes are for their molecular properties; however, here we consider crystalline metallocenes and their potential as active, multiferroic, materials.

The discovery of ferrocene, which has two cyclopentadienyl $\left(\mathrm{Cp}\right.$, or $\left.\mathrm{C}_{5} \mathrm{H}_{5}{ }^{-}\right)$rings with a transition metal sandwiched between, was the beginning of the field of organometallic chemistry, with the 1973 Nobel prize awarded to Geoffrey Wilkinson and Ernst Otto Fisher [4,5]. There are many possible metallocenes, since the charge of the cyclic conjugated ligands $-\mathrm{C}_{n} \mathrm{H}_{n}{ }^{\mathrm{q}}(n=3-8)$ can be positive, negative, or neutral [6]; the hydrogen atom(s) can be replaced by isovalent functional groups $(-X, X=F$, $\mathrm{Cl}, \mathrm{Br}, \mathrm{I}, \mathrm{OH}, \mathrm{CH}_{3}$, etc.) [7-10]; the $-\mathrm{C}_{5} \mathrm{H}_{5}{ }^{-}$ring can be replaced by other heterocycles; the Fe cation can be replaced by other transition metals with different spin states [11-13], and metallocene molecules can be doubled [14] or coordinated by other molecules or ligands. Here, we explored building polar crystals through the crystallization of polar molecules. Ferrocene itself has no (when the rings thermally rotate) or only a small possible dipole moment (as a static molecule) since it is a symmetric molecule. It crystallizes in a monoclinic structure ( $\left.\mathrm{P} 2{ }_{1} / \mathrm{a}\right)$ at room temperature [15], which transforms metastably to triclinic at $164 \mathrm{~K}$ [16], or stably to orthorhombic [17]. The centrosymmetric staggered molecular structure within the P2 1 /a phase transfers into two slightly distinct types of non-centrosymmetric, almost eclipsed, ferrocene molecules within the triclinic phase [16,18,19]. Density functional theory (DFT) calculations show that the ferrocene molecule with a staggered configuration has a very weak dipole moment $(0.006 \mathrm{D})$, and the two types of molecules within the triclinic crystalline ferrocene increase to $0.08 \mathrm{D}$ and $0.04 \mathrm{D}$, respectively [20]. Recently, using first-principle calculations, Wu et al. [21] predicted that crystallized $\mathrm{M}\left(\mathrm{C}_{6} \mathrm{H}_{6}\right)$ and $\mathrm{M}\left(\mathrm{C}_{5} \mathrm{H}_{5}\right)$ nanowires become ferroelectric or even multiferroic, depending on the decorating functional groups. Nanowires of $\mathrm{M}(\mathrm{Cp}) \infty(\mathrm{M}=\mathrm{Ti}, \mathrm{Cr}, \mathrm{Fe})$ 
are predicted to be ferromagnetic half-metals, and $\left[\mathrm{M}\left(\mathrm{FeC} \mathrm{p}_{2}\right)\right] \infty(\mathrm{M}=\mathrm{Sc}, \mathrm{Ti}, \mathrm{V}, \mathrm{Mn})$ are ferromagnetic semiconductors $[22,23]$.

\section{Assessing van der Waals (vdW) Functionals}

Density functional theory gives reasonable geometries for metallocene molecules [24-26]. $\mathrm{Xu}$ et al. [27] compared several gradient-corrected functionals, as well as the local density approximation (LDA), and found that the B3LYP functional gives the best agreement between the experimental and theoretical molecular geometry. However, for molecular crystals, accurate van der Waals forces must be included. We computed the equilibrium crystalline geometry starting from the experimental room temperature structure, the magnetic ground states, and magnetic moments of ferrocene, nickelocene, cobaltocene, and vanadocene, which are experimentally available, to assess the performance of the vdW functionals DFT-D, rVV10, and vdW-DF2 [28-30].

We found that the vdW-DF2 functional is most accurate of the three (Table 1), and provides quite good agreement with experiments, within $\sim 3 \%$ of the observed cell volumes. In contrast, DFT-D and rVV10 methods significantly underestimate cell volumes. Therefore, we employed the vdW-DF2 functional for the subsequent calculations.

Table 1. Static properties for ordered crystalline metallocenes. Results for magnetic order (FM, AFM and $\mathrm{NM}$ denote ferromagnetic, antiferromagnetic and non-spin-polarized, respectively), energy difference $\left(\Delta E_{\mathrm{MS}}, \mathrm{eV} /\right.$ molecule) relative to magnetic ground state, magnetic moment $(M, \mu \mathrm{B} /$ molecule), and cell volume $\left(V_{\text {cell }}, \AA^{3}\right)$, of ferrocene, nickelocene, cobaltocene, and vanadocene, calculated using DFT-D, rVV10, and vdW-DF2 functionals. For ferrocene, a starting configuration with AFM or FM converges to the non-magnetic state for all three functionals. Therefore, the magnetic moment for the FM state is fixed to $8.0 \mu \mathrm{B}$ per unit cell for comparison. Note that $\mathrm{Ni}_{2} \mathrm{C}_{20} \mathrm{H}_{20}$ with an $\mathrm{AFM}$ starting configuration also converges to non-magnetic with the rVV10 functional.

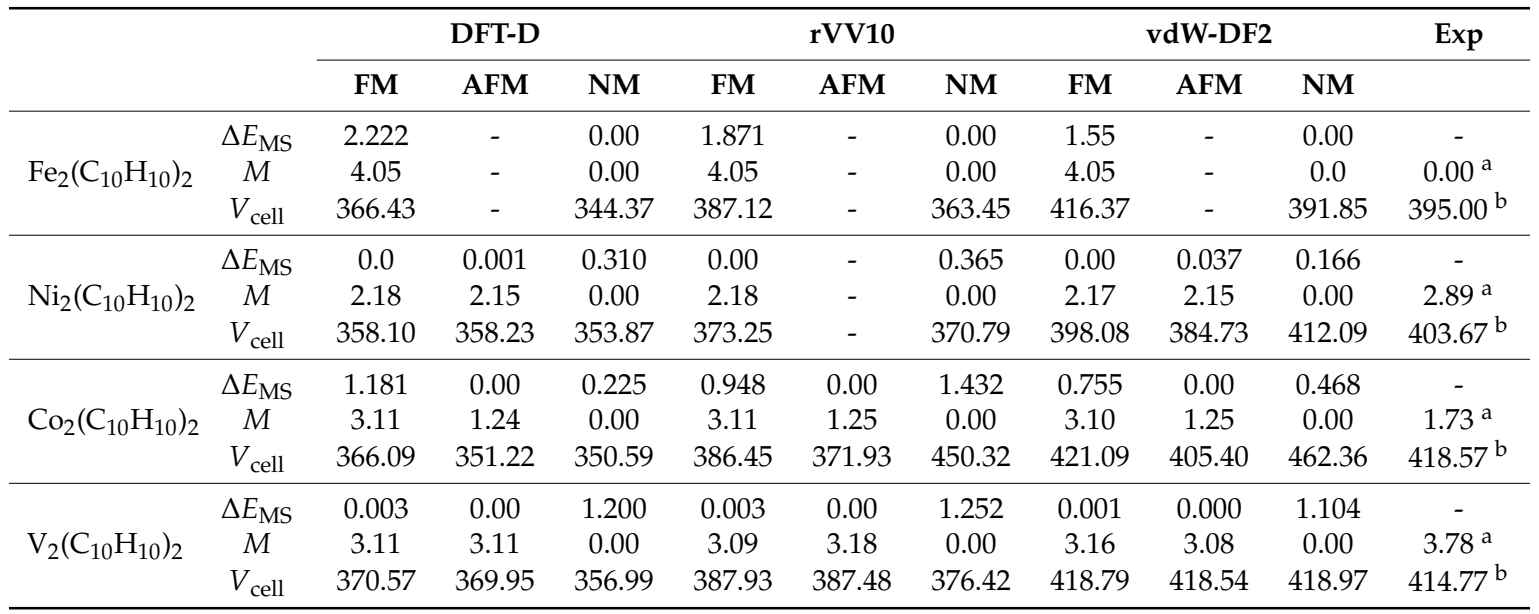

${ }^{\mathrm{a}}$ Reference [31]; ${ }^{\mathrm{b}}$ References [15,28-30], for ferrocene, nickelocene, cobaltocene, and vanadocene, respectively.

\section{Dipole Moments for Isolated Molecules}

Next, we considere maximizing the dipole moments for isolated molecules. We relaxed the isolated molecules in periodic cells of various sizes, to compare directly with our plane wave pseudopotential computations using the same basis set for crystals [32]. We computed the dipole moments using maximally localized Wannier functions [33]. We found that the dipole moment of an isolated ferrocene molecule with an eclipsed configuration is $0.08 \mathrm{D}$, with the direction being parallel to the two Cp rings (Figure 1, Table 2), consistent with simulation results of J. M. B.-García, et al. [20]. The molecular dipole moments can be increased by ligand decorations or by replacing the $\mathrm{Cp}$ with heterocyclic rings. The replacing of one $\mathrm{C}$ atom by $\mathrm{Si}$ increases the dipole moment substantially to $0.25 \mathrm{D}$ for $\mathrm{Fe}\left(\mathrm{C}_{9} \mathrm{H}_{10} \mathrm{Si}\right)$, with the positive polarization towards $\mathrm{Si}$ and the unsubstituted $\mathrm{Cp}$ ring. This 
is consistent with the weaker electronegativity of $\mathrm{Si}$ relative to $\mathrm{C}$. When we replaced one $\mathrm{H}$ atom by $\mathrm{F}$, we found more electrons on the $-\mathrm{C}_{5} \mathrm{H}_{4} \mathrm{~F}^{-}$ring than on the $\mathrm{Cp}$ side, consistent with the stronger electronegativity of $\mathrm{F}$ with respect to $\mathrm{H}$. Therefore, $\mathrm{Fe}\left(\mathrm{C}_{10} \mathrm{H}_{9} \mathrm{~F}\right)$ has a large dipole moment $(1.70 \mathrm{D})$, pointing away from the unsubstituted $\mathrm{Cp}$ ring. Experimentally, metallocenes with 1-5 halogens per ring have been synthesized [10,34-39]. When we replaced $F$ with heavier halogens, we found that the dipole moment increased to $1.77,1.82$, and 1.81 D in $\mathrm{Fe}\left(\mathrm{C}_{10} \mathrm{H}_{9} \mathrm{Cl}\right), \mathrm{Fe}\left(\mathrm{C}_{10} \mathrm{H}_{9} \mathrm{Br}\right)$, and $\mathrm{Fe}\left(\mathrm{C}_{10} \mathrm{H}_{9} \mathrm{I}\right)$, respectively (Table 3). We propose that the increase in dipole moment was simply due to the larger bond lengths of the positive and negative charges, opposite to what one would expect from electronegativity, which decreases with increasing atomic number.

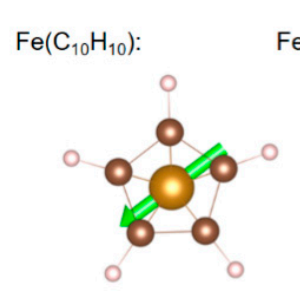

$\mathrm{V}\left(\mathrm{C}_{9} \mathrm{H}_{9} \mathrm{~N}\right)$ :

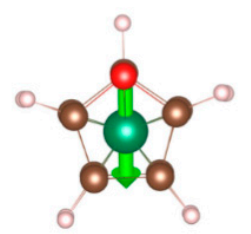

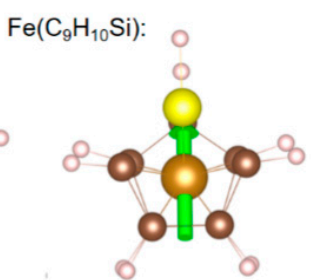

$\mathrm{Cr}\left(\mathrm{C}_{9} \mathrm{H}_{9} \mathrm{~N}\right)$ :

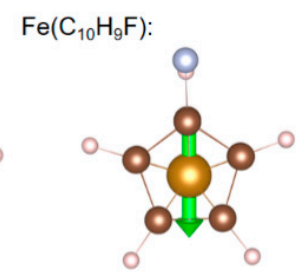

$\mathrm{Mn}\left(\mathrm{C}_{9} \mathrm{H}_{9} \mathrm{~N}\right)$ :

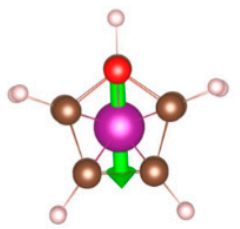

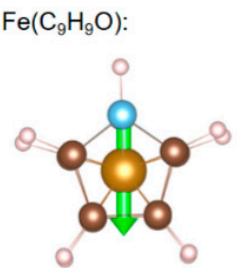

$\mathrm{Co}\left(\mathrm{C}_{9} \mathrm{H}_{9} \mathrm{~N}\right)$ :

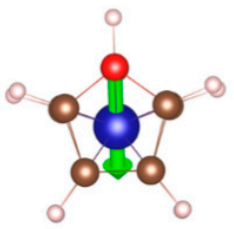

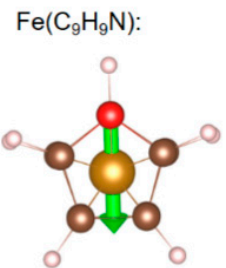

$\mathrm{Ni}\left(\mathrm{C}_{9} \mathrm{H}_{9} \mathrm{~N}\right)$ :

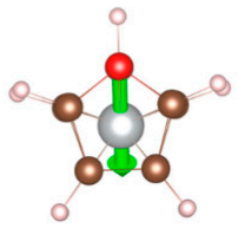

Figure 1. The structure and dipole moments of isolated $\mathrm{Fe}\left(\mathrm{C}_{10} \mathrm{H}_{10}\right), \mathrm{Fe}\left(\mathrm{C}_{9} \mathrm{H}_{10} \mathrm{Si}\right), \mathrm{Fe}\left(\mathrm{C}_{10} \mathrm{H}_{9} \mathrm{~F}\right)$, $\mathrm{Fe}\left(\mathrm{C}_{9} \mathrm{H}_{9} \mathrm{O}\right), \mathrm{Fe}\left(\mathrm{C}_{9} \mathrm{H}_{9} \mathrm{~N}\right), \mathrm{V}\left(\mathrm{C}_{9} \mathrm{H}_{9} \mathrm{~N}\right), \mathrm{Cr}\left(\mathrm{C}_{9} \mathrm{H}_{9} \mathrm{~N}\right), \mathrm{Mn}\left(\mathrm{C}_{9} \mathrm{H}_{9} \mathrm{~N}\right), \mathrm{Co}\left(\mathrm{C}_{9} \mathrm{H}_{9} \mathrm{~N}\right)$, and $\mathrm{Ni}\left(\mathrm{C}_{9} \mathrm{H}_{9} \mathrm{~N}\right)$ molecules with an eclipsed starting configuration. The green arrows denote the direction of the dipole moment for each molecule. Key: C: brown; Fe: shallow brown; H: pink; O: light blue; N: red; V: cyan; Cr: dark blue; Mn: purple; Co: blue; Ni: silver.

Next, we considered replacing a $-\mathrm{C}_{5} \mathrm{H}_{5}{ }^{-}$ring by a charge neutral furan $\left(-\mathrm{C}_{4} \mathrm{H}_{4} \mathrm{O}\right)$. This sandwich structure was synthesized experimentally for the Ru-metallocene [40]. The iron atom donated one less electron to the neutral $-\mathrm{C}_{4} \mathrm{H}_{4} \mathrm{O}$ ring, giving rise to $\mathrm{Fe}^{+}\left(\mathrm{d}^{7}\right)$, and 19 electrons for the molecule. We obtained, for furanferrocene $\mathrm{Fe}\left(\mathrm{C}_{9} \mathrm{H}_{9} \mathrm{O}\right)$, a magnetic moment of $1 \mu \mathrm{B}$ (indicating a low-spin iron), and a large dipole moment $(1.32 \mathrm{D})$. When we replaced a $\mathrm{Cp}$ ring with pyrrole $\left(-\mathrm{C}_{4} \mathrm{H}_{4} \mathrm{~N}^{-}\right)$, we found a larger dipole moment $(2.08 \mathrm{D})$. The dipole moment of $\mathrm{Fe}\left(\mathrm{C}_{9} \mathrm{H}_{9} \mathrm{~N}\right)$ points from the $\mathrm{N}$ atom to the other side of the heterocycle and to the unsubstituted $\mathrm{Cp}$ ring. The electron-donating capacity of $\mathrm{B}, \mathrm{P}, \mathrm{As}, \mathrm{Sb}$, and $\mathrm{Bi}$ are weaker than that of $\mathrm{N}$; however, the dipole moment decreases to $0.87,1.71,1.42,0.70$ and $0.52 \mathrm{D}$ in $\mathrm{Fe}\left(\mathrm{C}_{9} \mathrm{H}_{9} \mathrm{~B}\right), \mathrm{Fe}\left(\mathrm{C}_{9} \mathrm{H}_{9} \mathrm{P}\right), \mathrm{Fe}\left(\mathrm{C}_{9} \mathrm{H}_{9} \mathrm{As}\right), \mathrm{Fe}\left(\mathrm{C}_{9} \mathrm{H}_{9} \mathrm{Sb}\right)$, and $\mathrm{Fe}\left(\mathrm{C}_{9} \mathrm{H}_{9} \mathrm{Bi}\right)$, respectively (Table 4).

The magnitude of the dipole moment of azametallocene molecules shows a strong dependence on the atomic number of the cations (Table 2). Similar to $\mathrm{M}_{2}\left(\mathrm{C}_{10} \mathrm{H}_{10}\right)_{2}$, the cations in azametallocene molecules donate two electrons (one to $-\mathrm{C}_{5} \mathrm{H}_{5}{ }^{-}$and the other to $-\mathrm{C}_{4} \mathrm{H}_{4} \mathrm{~N}^{-}$) to form a stable aromatic configuration having $4 \mathrm{k}+2\left(\mathrm{k}\right.$ is an integer) electrons [41]. We found for vanadium in $\mathrm{V}\left(\mathrm{C}_{9} \mathrm{H}_{9} \mathrm{~N}\right)$ that the most stable $3 d$ electronic configuration is the one with three parallel spins. Iron in $\mathrm{Fe}(\mathrm{C} 9 \mathrm{H} 9 \mathrm{~N})$ is in a low spin state with zero magnetic moment. These results agree well with $\mathrm{TM}_{2}\left(\mathrm{C}_{10} \mathrm{H}_{10}\right)_{2}(\mathrm{Table} 1)$, as the substitution of $-\mathrm{C}_{5} \mathrm{H}_{5}-$ by $-\mathrm{C}_{4} \mathrm{H}_{4} \mathrm{~N}^{-}$does not change the number of electrons on the cations. 
Table 2. Number of $3 d$ electrons on the transition metal (TM) ions (N); magnetic moment $(\mathrm{M}, \mu \mathrm{B})$, dipole moment ( $\mu$, D) of isolated metallocene molecules; rotation barriers $\left(E_{\text {rotation }}=E_{\text {staggered }}-E_{\text {eclipsed }}, \mathrm{kJ} / \mathrm{mol}\right)$ and dipole moment differences $\left(\Delta \mu=\mu_{\text {staggered }}-\mu_{\text {eclipsed }}, \mathrm{D}\right)$ between the two different configurations.

\begin{tabular}{|c|c|c|c|c|c|c|c|c|c|c|}
\hline & $\mathrm{Fe}\left(\mathrm{C}_{10} \mathrm{H}_{10}\right)$ & $\mathrm{Fe}\left(\mathrm{C}_{9} \mathrm{SiH}_{10}\right)$ & $\mathrm{Fe}\left(\mathrm{C}_{10} \mathrm{H}_{9} \mathrm{~F}\right)$ & $\mathrm{Fe}\left(\mathrm{C}_{9} \mathrm{H}_{9} \mathrm{O}\right)$ & $\mathrm{Fe}\left(\mathrm{C}_{9} \mathrm{H}_{9} \mathrm{~N}\right)$ & $\mathrm{V}\left(\mathrm{C}_{9} \mathrm{H}_{9} \mathrm{~N}\right)$ & $\mathrm{Cr}\left(\mathrm{C}_{9} \mathrm{H}_{9} \mathrm{~N}\right)$ & $\operatorname{Mn}\left(\mathrm{C}_{9} \mathrm{H}_{9} \mathrm{~N}\right)$ & $\mathrm{Co}\left(\mathrm{C}_{9} \mathrm{H}_{9} \mathrm{~N}\right)$ & $\mathrm{Ni}\left(\mathrm{C}_{9} \mathrm{H}_{9} \mathrm{~N}\right)$ \\
\hline$N$ & 6 & 6 & 6 & 7 & 6 & 3 & 4 & 5 & 7 & 8 \\
\hline$M$ & 0 & 0 & 0 & 1 & 0 & 3 & 2 & 1 & 1 & 2 \\
\hline$\mu$ & 0.08 & 0.25 & 1.70 & 1.32 & 2.08 & 1.75 & 2.37 & 1.84 & 2.20 & 2.80 \\
\hline$E_{\text {rotation }}$ & 2.61 & 3.38 & 2.41 & -3.76 & 2.22 & 0.29 & 0.97 & 2.12 & 1.06 & -1.74 \\
\hline$\Delta \mu$ & -0.01 & 0.04 & 0.04 & 0.07 & -0.25 & 0.31 & -0.40 & 0.26 & 0.02 & -0.03 \\
\hline
\end{tabular}


Table 3. Dipole moment $(\mu, \mathrm{D})$ of isolated metallocene molecules with an eclipsed configuration; activation energy $\left(E_{\text {act }}=E_{\text {transition state }}-E_{\text {ground state }}, \mathrm{kJ} / \mathrm{mol}\right)$ and dipole moment difference $(\Delta \mu=$ $\left.\mu_{\text {transition state }}-\mu_{\text {ground state }}, \mathrm{D}\right)$ between the transition state and the ground state. The number of $3 d$ electrons on Fe is 6, and the magnetic moment of each isolated molecule is 0 .

\begin{tabular}{cccc}
\hline & $\mathbf{F e}\left(\mathbf{C}_{\mathbf{1 0}} \mathbf{H}_{\mathbf{9}} \mathbf{C l}\right)$ & $\mathbf{F e}\left(\mathbf{C}_{\mathbf{1 0}} \mathbf{H}_{\mathbf{9}} \mathbf{B r}\right)$ & $\mathbf{F e}\left(\mathbf{C}_{\mathbf{1 0}} \mathbf{H}_{\mathbf{9}} \mathbf{I}\right)$ \\
\hline$\mu$ & 1.77 & 1.82 & 1.81 \\
$E_{\mathrm{act}}$ & 2.19 & 2.16 & 2.01 \\
$\Delta \mu$ & 0.01 & -0.21 & -0.02 \\
\hline
\end{tabular}

Table 4. Dipole moment $(\mu, \mathrm{D})$ of isolated metallocene molecules with an eclipsed configuration; activation energy $\left(E_{\text {act }}=E_{\text {transition state }}-E_{\text {ground state }}, \mathrm{kJ} / \mathrm{mol}\right)$ and dipole moment difference $(\Delta \mu=$ $\left.\mu_{\text {transition state }}-\mu_{\text {ground state }}, \mathrm{D}\right)$ between the transition state and the ground state. The number of the $3 d$ electrons rest on $\mathrm{Fe}$ is 6 , and the magnetic moment of the isolated molecules is 0 .

\begin{tabular}{|c|c|c|c|c|c|}
\hline & $\mathrm{Fe}\left(\mathrm{C}_{9} \mathrm{H}_{9} \mathrm{~B}\right)$ & $\mathrm{Fe}\left(\mathrm{C}_{9} \mathrm{H}_{9} \mathrm{P}\right)$ & $\mathrm{Fe}\left(\mathrm{C}_{9} \mathrm{H}_{9} \mathrm{As}\right)$ & $\mathrm{Fe}\left(\mathrm{C}_{9} \mathrm{H}_{9} \mathrm{Sb}\right)$ & $\mathrm{Fe}\left(\mathrm{C}_{9} \mathrm{H}_{9} \mathrm{Bi}\right)$ \\
\hline$\mu$ & 0.87 & 1.71 & 1.42 & 0.70 & 0.52 \\
\hline$E_{\text {act }}$ & 3.41 & 2.60 & 3.60 & 3.08 & 3.19 \\
\hline$\Delta \mu$ & 0.10 & 0.01 & -0.11 & 0.16 & 0.30 \\
\hline
\end{tabular}

The relative stabilities and dipole moments of isolated metallocene molecules with two ring rotations show low rotation barriers $\left(E_{\text {rotation }}=E_{\text {staggered }}-E_{\text {eclipsed }}\right)$, which are lower than the rotation barrier within the crystalline ferrocene $(4.4 \pm 0.5 \mathrm{~kJ} / \mathrm{mol})$, [42] and comparable to $\sim k_{\mathrm{B}} \mathrm{T}$ at room temperature ( $2.6 \mathrm{~kJ} / \mathrm{mol}$, Tables $2-4)$. Therefore, the rotation of the $\mathrm{Cp}$ rings is unhindered at room temperature. The negative values of $E_{\text {rotation }}$ for $\mathrm{Fe}\left(\mathrm{C}_{9} \mathrm{H}_{9} \mathrm{O}\right)$ and $\mathrm{Ni}\left(\mathrm{C}_{9} \mathrm{H}_{9} \mathrm{~N}\right)$ suggest that the staggered configuration, rather than the eclipsed configuration, is the ground state. Furthermore, we found that the dipole moments are dependent on the relative rotation of the rings. Upon rotation from the ground state to the transition state, the dipole moments vary by $10 \%$, suggesting that ring rotation can be activated by applying time varying electric fields.

\section{Crystalline Polar Metallocenes}

Returning to crystalline properties, we considere polar metallocenes composed of molecules that display promising dipole moments. Azaferrocene $\mathrm{Fe}_{2}\left(\mathrm{C}_{9} \mathrm{H}_{9} \mathrm{~N}\right)_{2}$ is isomorphous with ferrocene and crystallizes at room temperature in the monoclinic structure $[43,44]$. Thus, we first constructed the initial monoclinic azaferrocene using the room temperature [15] and low temperature [45] monoclinic ferrocene as prototype structures. They were found to be polar at their ground state, as shown in Figure 2a (M1) and b (M2), respectively. The net polarization depends on the magnitude as well as the arrangement of the dipole moments of the two constituent molecules in the unit cell. Therefore, we further consider two extreme cases, namely, the two constituent molecules antiparallel (AFE) and almost parallel (FE) to each other, relaxed from the triclinic ferrocene structure [10]. Within the AFE configuration, the dipole moments of the two molecules cancel each other, giving rise to a zero polarization (Figure 2c). The almost parallel arrangement of the dipole moments within the FE configuration yields the largest polarization among various structures investigated (Figure 2d). 

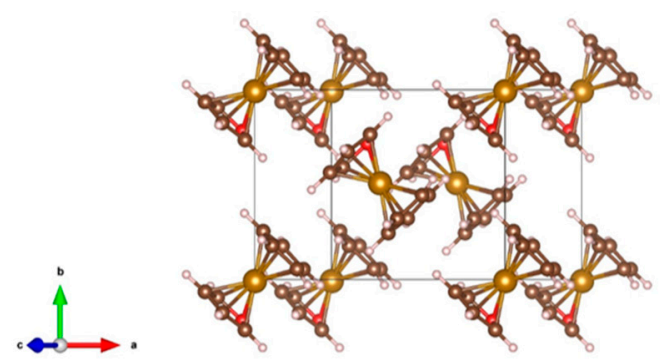

(a)

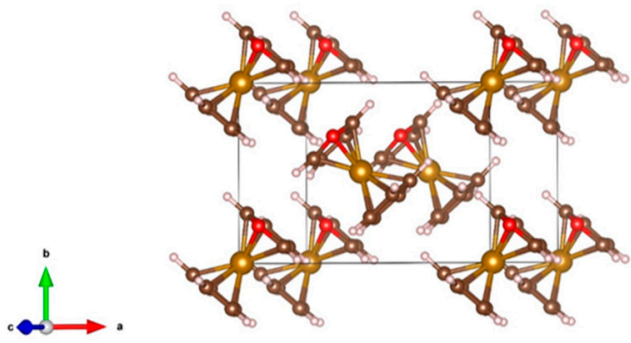

(b)

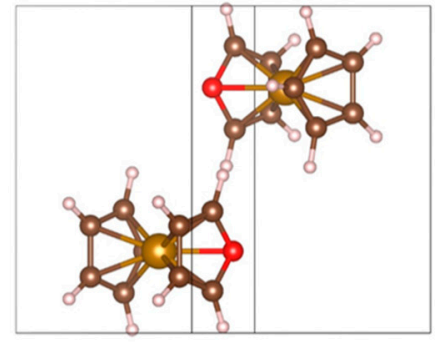

(c)

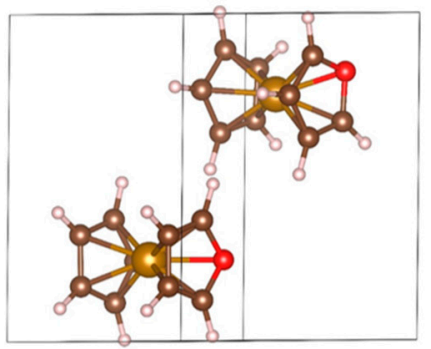

(d)

Figure 2. Optimized crystal structure of azaferrocene constructed using the (a) room temperature and (b) low temperature monoclinic ferrocenes as prototype structures; triclinic ferrocene with the two constituent azaferrocene molecules (c) antiparallel (AFE) and (d) almost parallel (FE) to each other. Azaferrocene constructed using the two monoclinic ferrocene structures has a polar ground state. The two structures are denoted as M1 and M2, respectively. Key: C: dark brown; Fe: brown; H: pink; N: red.

The energy differences of the AFE configuration with respect to the FE configuration $\left(\Delta E_{\text {polar }}=\right.$ $E_{\mathrm{FE}}-E_{\mathrm{AFE}}, \mathrm{meV} /$ per cell) are also shown in Table 5 to evaluate their relative stabilities. $\mathrm{Mn}_{2}\left(\mathrm{C}_{9} \mathrm{H}_{9} \mathrm{~N}\right)_{2}$ has a negative $\Delta E_{\text {polar }}$, which is highly desirable as the FE configuration is the ground state. All the other systems investigated have an AFE configuration. To investigate the stability of the crystals, we calculated the binding energy by $E_{\text {bind }}=E_{\text {molecule }}-E_{\text {ground }} / 2$, where $E_{\text {molecule }}$ is the energy of the isolated molecules at their ground state, and $E_{\text {ground }}$ is the total energy per unit cell of triclinic polar metallocenes with the FE configuration at their magnetic ground state. The binding energies are large, ranging from 0.57 to $0.91 \mathrm{eV}$, and the relaxed cell volumes of azametallocenes decrease as the computed binding energies increase. The low energy differences between the AFE and FE configuration together with the large binding energies, suggest that such systems with ferroelectric ordering can be fabricated by applying an external bias field during crystallization and could be stable over a wide temperature range.

Table 5. Cell volume $\left(V_{\text {cell }}, \AA^{3}\right)$ at magnetic ground state, energy difference of the triclinic polar metallocenes with the $\mathrm{FE}$ configuration with respect to the $\mathrm{AFE}$ configuration $\left(\Delta E_{\text {polar }}=E_{\mathrm{FE}}-E_{\mathrm{AFE}}\right.$, $\mathrm{meV}$ per cell), binding energy $\left(E_{\text {bind }}=E_{\text {molecule }}-E_{\text {ground }} / 2, \mathrm{eV}\right.$ per molecule).

\begin{tabular}{ccccccccc}
\hline & $\mathbf{F e}_{\mathbf{2}}\left(\mathbf{C}_{\mathbf{1 0}} \mathbf{H}_{\mathbf{9}} \mathbf{F}\right)_{\mathbf{2}}$ & $\mathbf{F e}_{\mathbf{2}}\left(\mathbf{C}_{\mathbf{9}} \mathbf{H}_{\mathbf{9}} \mathbf{O}\right)_{\mathbf{2}}$ & $\mathbf{V}_{\mathbf{2}}\left(\mathbf{C}_{\mathbf{9}} \mathbf{H}_{\mathbf{9}} \mathbf{N}\right)_{\mathbf{2}}$ & $\mathbf{C r}_{\mathbf{2}}\left(\mathbf{C}_{\mathbf{9}} \mathbf{H}_{\mathbf{9}} \mathbf{N}\right)_{\mathbf{2}}$ & $\mathbf{M n}_{\mathbf{2}}\left(\mathbf{C}_{\mathbf{9}} \mathbf{H}_{\mathbf{9}} \mathbf{N}\right)_{\mathbf{2}}$ & $\mathbf{F e}_{\mathbf{2}}\left(\mathbf{C}_{\mathbf{9}} \mathbf{H}_{\mathbf{9}} \mathbf{N}\right)_{\mathbf{2}}$ & $\mathbf{C o}_{\mathbf{2}}\left(\mathbf{C}_{\mathbf{9}} \mathbf{H}_{\mathbf{9}} \mathbf{N}\right)_{\mathbf{2}}$ & $\mathbf{N i}_{\mathbf{2}}\left(\mathbf{C}_{\mathbf{9}} \mathbf{H}_{\mathbf{9}} \mathbf{N}\right)_{\mathbf{2}}$ \\
\hline$V_{\text {cell }}$ & 404.58 & 382.58 & 404.87 & 392.73 & 386.79 & 378.17 & 385.17 & 382.98 \\
$\Delta E_{\text {polar }}$ & 80.96 & 74.96 & 12.22 & 5.99 & -0.87 & 17.67 & 44.78 & 6.53 \\
$E_{\text {bind }}$ & 0.89 & 0.76 & 0.90 & 0.85 & 0.76 & 0.91 & 0.87 & 0.57 \\
\hline
\end{tabular}

We further investigated the magnetic and electronic properties of polar metallocenes with the FE configuration. We computed the energy differences between the antiferromagnetic and ferromagnetic states $\left(\Delta E_{\mathrm{MS}}=E_{\mathrm{AFM}}-E_{\mathrm{FM}}\right)$ to estimate the exchange splitting, as shown in Table 6. Like ferrocene, $\mathrm{Fe}_{2}\left(\mathrm{C}_{10} \mathrm{H}_{9} \mathrm{~F}\right)_{2}$ and $\mathrm{Fe}_{2}\left(\mathrm{C}_{9} \mathrm{H}_{9} \mathrm{~N}\right)_{2}$ are non-magnetic. $\mathrm{Fe}_{2}\left(\mathrm{C}_{9} \mathrm{H}_{9} \mathrm{O}\right)_{2}$ has an AFM ground state. Similar to $\mathrm{V}_{2}\left(\mathrm{C}_{10} \mathrm{H}_{10}\right)_{2}$ and $\mathrm{Ni}_{2}\left(\mathrm{C}_{10} \mathrm{H}_{10}\right)_{2}$ (Table 1), we found that $\mathrm{V}_{2}\left(\mathrm{C}_{9} \mathrm{H}_{9} \mathrm{~N}\right)_{2}, \mathrm{Cr}_{2}\left(\mathrm{C}_{9} \mathrm{H}_{9} \mathrm{~N}\right)_{2}$, and $\mathrm{Ni}_{2}\left(\mathrm{C}_{9} \mathrm{H}_{9} \mathrm{~N}\right)_{2}$ have AFM ground states, which are more stable than the FM states by 6.19, 1.60, and $4.93 \mathrm{meV}$ per unit 
cell, respectively. Unlike $\mathrm{Co}_{2}\left(\mathrm{C}_{10} \mathrm{H}_{10}\right)_{2}, \mathrm{Co}_{2}\left(\mathrm{C}_{9} \mathrm{H}_{9} \mathrm{~N}\right)_{2}$ has a FM ground state, and has the largest $\Delta E_{\mathrm{MS}}$ $(47.57 \mathrm{meV})$ among different azametallocenes investigated. Similarly, $\mathrm{Mn}_{2}\left(\mathrm{C}_{9} \mathrm{H}_{9} \mathrm{~N}\right)_{2}$ has a FM ground state with a quite small energy difference $(0.47 \mathrm{meV})$. Therefore, $\mathrm{Mn}_{2}\left(\mathrm{C}_{9} \mathrm{H}_{9} \mathrm{~N}\right)_{2}$ is the most promising as ferroic material, since FM and FE ordering can be realized simultaneously.

Table 6. Magnetic ground state (MGS), energy difference between AFM and FM states $\left(\Delta E_{\mathrm{MS}}=\right.$ $E_{\mathrm{AFM}}-E_{\mathrm{FM}}, \mathrm{meV} /$ per cell), magnetic moment $\left(M_{\mathrm{cell}}, \mu \mathrm{B}\right)$, polarization $\left(P, \mu \mathrm{C} / \mathrm{cm}^{2}\right)$ by Berry's phase calculations, and polarization $\left(P^{*}, \mu \mathrm{C} / \mathrm{cm}^{2}\right)$ calculated by summing the dipole moment of isolated molecules for triclinic polar metallocenes with the FE configuration.

\begin{tabular}{|c|c|c|c|c|c|c|c|c|}
\hline & $\mathrm{Fe}_{2}\left(\mathrm{C}_{10} \mathrm{H}_{9} \mathrm{~F}\right)_{2}$ & $\mathrm{Fe}_{2}\left(\mathrm{C}_{9} \mathrm{H}_{9} \mathrm{O}\right)_{2}$ & $\mathrm{~V}_{2}\left(\mathrm{C}_{9} \mathrm{H}_{9} \mathrm{~N}\right)_{2}$ & $\mathrm{Cr}_{2}\left(\mathrm{C}_{9} \mathrm{H}_{9} \mathrm{~N}\right)_{2}$ & $\mathrm{Mn}_{2}\left(\mathrm{C}_{9} \mathrm{H}_{9} \mathrm{~N}\right)_{2}$ & $\mathrm{Fe}_{2}\left(\mathrm{C}_{9} \mathrm{H}_{9} \mathrm{~N}\right)_{2}$ & $\mathrm{Co}_{2}\left(\mathrm{C}_{9} \mathrm{H}_{9} \mathrm{~N}\right)_{2}$ & $\mathrm{Ni}_{2}\left(\mathrm{C}_{9} \mathrm{H}_{9} \mathrm{~N}\right)_{2}$ \\
\hline MGS & 1 & AFM & AFM & AFM & FM & / & FM & AFM \\
\hline$\Delta E_{\mathrm{MS}}$ & / & -7.92 & -6.20 & -1.60 & 0.47 & / & 47.57 & -4.93 \\
\hline$P$ & 4.40 & 3.16 & 5.03 & 6.06 & 5.43 & 5.56 & 5.79 & 6.56 \\
\hline$P^{*}$ & 2.72 & 1.91 & 2.77 & 3.92 & 3.07 & 3.55 & 3.69 & 4.80 \\
\hline
\end{tabular}

With an FE configuration, the metallocene crystals formed from molecules with large dipole moments show large polarizations. The large polarizations observed for azametallocenes (e.g., $>5 \mu \mathrm{C} / \mathrm{cm}^{2}$, Table 6) with respect to $\mathrm{Fe}_{2}\left(\mathrm{C}_{10} \mathrm{H}_{9} \mathrm{~F}\right)_{2}$ and $\mathrm{Fe}_{2}\left(\mathrm{C}_{9} \mathrm{H}_{9} \mathrm{O}\right)_{2}$, are due to the large dipole moments of the component molecules. Similar to the phenomena observed for water [46,47], the polarization for the crystalline phase is about 30-40\% higher than the values obtained based on the dipole moments for isolated molecules. This is due to the polarization of the molecules by the local self-consistent electrical field, and indicates high polarizabilities. Although the polarization of azametallocenes is smaller than inorganic perovskites (e.g., $\sim 30 \mu \mathrm{C} / \mathrm{cm}^{2}$ for $\mathrm{BaTiO}_{3}$ [48]), a large piezoelectric response is possible, since metallocenes rae mechanically softer.

\section{Materials and Methods}

All the calculations were performed using the pseudopotential plane-wave method implemented in the Quantum Espresso code [32]. Three different van der Waals functionals, namely, DFT-D, rVV10, and vdW-DF2, were incorporated to describe the van der Waals interactions [49-54]. The van der Waals interaction is part of the correlation energy, and can be applied to the different exchange functionals. In particular, in Quantum Espresso, the non-local functionals vdW-DF2 and rVV10 are used together with the revised Perdew-Wang functional (rPW86) [55,56], and the DFT-D correction was applied to the generalized gradient approximation of Perdew, Burke, and Ernzerhof (PBE-GGA) [57].

The lattice constants as well as atomic positions are optimized until the forces were smaller than $0.01 \mathrm{eV} / \AA$. The kinetic energy cutoffs for wavefunctions and charge density were set to 544.22 (40) and 2721.13 (200) eV(Ry), respectively. For crystalline metallocenes, the Brillouin zone was sampled by the Monkhorst-Pack scheme $(4 \times 4 \times 4 \mathrm{k}$ points for structure optimization, $6 \times 6 \times 6 \mathrm{k}$ points for the subsequent self-consistent and property calculations). The 'isolated molecules' were simulated by putting the molecules into fixed unit cells with different sizes. We found unit cells with a size of $24 \times$ $24 \times 24 \AA^{3}$ were large enough to well describe the internal stress and dipole moment of the isolated molecules. Maximally localized Wannier functions were generated by the Wannier90 code [33] to determine the negative charge center, based on which the dipole moments of the isolated molecules were calculated. GBRV pseudopotentials were employed for all the calculations [58].

\section{Conclusions}

We found polar metallocenes to be a worthwhile group to study as new active materials. Only recently has first-principles study of these systems become possible with new local van der Waals functionals, which we found to be indispensable. The vdW-DF2 functional gives accurate predictions for the structures and magnetic ground states of metallocene molecules and crystals. The dipole moment of isolated ferrocene molecules could be effectively tuned by ligand decorations or by replacing 
the $\mathrm{Cp}$ with heterocyclic rings. The magnetic moment of the ferrocene molecules could also be tuned by changing the charge of the cyclic conjugated ligands and/or by substitution of iron with other cations that had a different spin state. Our results suggest that crystalline polar metallocenes are worthy of study as potential ferroelectrics and multiferroics.

Author Contributions: R.E.C. conceived the idea; H.Z., B.Y.Y., and R.E.C. performed the simulations; H.Z. and R.E.C. designed the figures and analyzed the results; H.Z. drafted the manuscript; R.E.C. provided primary comments and editing; all authors approved the final manuscript.

Funding: This work is partly supported by the U. S. Office of Naval Research Grants No. N00014-12-1-1038, N00014-14-1-0516, and N00014-17-1-2768, the Carnegie Institution for Science, and the European Research Council Advanced Grant ToMCaT.

Acknowledgments: We thank Karlheinz Sünkel for helpful discussions. The authors gratefully acknowledge the Gauss Center for Supercomputing e.V. (www.gauss-centre.eu) for funding this project by providing computing time on the GCS Supercomputer SuperMUC at Leibniz Supercomputing Centre (LRZ, www.lrz.de).

Conflicts of Interest: The authors declare no conflict of interest.

\section{References}

1. Nicolaev, G.A.; Nicolaev, A. Transport in ferrocene single molecules for terahertz applications. Phys. Chem. Chem. Phys. 2014, 16, 5 .

2. Cunha, T.F.D.; Calderini, D.; Skouteris, D. Analysis of Partition Functions for Metallocenes: Ferrocene, Ruthenocene, and Osmocene. J. Phys. Chem. A. 2016, 120, 5282-5287. [CrossRef] [PubMed]

3. Wang, P.; Jiang, X.; Hu, J.; Huang, X.; Zhao, J.; Ahuja, R. Prediction of huge magnetic anisotropies in 5d transition metallocenes. J. Phys. Condens. Matter. 2017, 29, 435802. [CrossRef] [PubMed]

4. Fischer, O.; Pfab, W. Cyclopentadien-Metallkomplexe, ein neuer Typ metallorganischer Verbindungen. Z. Nat. B 1952, 7, 3. [CrossRef]

5. Wilkinson, G.R.M.; Whiting, M.C. The Structure of Iron Bis-Cyclopentadienyl. J. Am. Chem. Soc. 1952, 74, 2125-2126. [CrossRef]

6. Frunzke, J.; Lein, M.; Frenking, G. Structures, Metal-Ligand Bond Strength, and Bonding Analysis of Ferrocene Derivatives with Group-15 Heteroligands $\mathrm{Fe}\left(\eta^{5}-\mathrm{E}_{5}\right)_{2}$ and $\mathrm{FeCp}\left(\eta^{5}-\mathrm{E}_{5}\right)(\mathrm{E}=\mathrm{N}, \mathrm{P}, \mathrm{As}, \mathrm{Sb})$. A Theoretical Study. Organometallics 2002, 21, 3351-3359. [CrossRef]

7. Dombrowski, K.E.; Baldwin, W.; Sheats, J.E. Metallocenes in biochemistry, microbiology and medicine. J. Organomet. Chem. 1986, 302, 26. [CrossRef]

8. Dunitz, J.D.; Orgel, L.E. Electronic Structure of Metal biscyclopentadienyls. J. Chem. Phys. 1955, 23, 954-958. [CrossRef]

9. Vargas-Caamal, A.; Pan, S.; Ortiz-Chi, F.; Cabellos, J.L.; Boto, R.A.; Contreras-Garcia, J.; Restrepo, A.; Chattaraj, P.K.; Merino, G. How strong are the metallocene-metallocene interactions? Cases of ferrocene, ruthenocene, and osmocene. Phys. Chem. Chem. Phys. 2016, 18, 550-556. [CrossRef]

10. Sünkel, K.; Weigand, S.; Hoffmann, A.; Blomeyer, S.; Reuter, C.G.; Vishnevskiy, Y.V.; Mitzel, N.W. Synthesis and Characterization of 1,2,3,4,5-Pentafluoroferrocene. J. Am. Chem. Soc. 2015, 137, 126-129. [CrossRef]

11. Sohn, Y.S.; Hendrickson, D.N.; Gray, H.B. Electronic Structure of Metallocenes. J. Am. Chem. Soc. 1971, 93, 3603-3612.

12. Haaland, A. Molecular Structure and Bonding in the 3d Metallocenes. Acc. Chem. Res. 1979, 12, 415-422. [CrossRef]

13. Little, W.F. Metallocenes. Surv. Prog. Chem. 1963, 1, 78.

14. Wu, X.; Zeng, X. Double Metallocene Nanowires. J. Am. Chem. Soc. 2009, 131, 14246-14248. [CrossRef] [PubMed]

15. Seiler, P.; Dunitz, J.D. A New Interpretation of the Disordered Crystal Structure of Ferrocene. Acta Cryst. 1979, 35, 1068-1074. [CrossRef]

16. Dunitz, J.D. Phase Changes and Chemical Reactions in Molecular Crystals. Acta Cryst. B 1995, 51, 619-631. [CrossRef]

17. Seiler, P.; Dunitz, J.D. Low-temperature Crystallization of Orthorhombic Ferrocene: Structure Analysis at 98 K. Acta Cryst. Sect. B-Struct. Sci. 1982, 38, 1741-1745. [CrossRef] 
18. Seiler, P.; Dunitz, J.D. The Structure of Triclinic Ferrocene at 101, 123 and 148 K. Acta Cryst. 1979, B35, 2020-2032. [CrossRef]

19. Edwards, J.W.; Kington, G.L.; Mason, R. The thermodynamic properties of ferrocene. Trans. Faraday Soc. 1960, 56, 660-667. [CrossRef]

20. Bermúdez-García, J.M.; Yáñez-Vilar, S.; Castro-García, S.; Señarís-Rodríguez, M.A.; Sánchez-Andújar, M. New properties in old systems: Cooperative electric order in ferrocene and ammonia-borane. RSC Adv. 2015, 5, 83818-83824. [CrossRef]

21. Wu, M.; Burton, J.D.; Tsymbal, E.Y.; Zeng, X.C.; Jena, P. Multiferroic Materials Based on Organic Transition-Metal Molecular Nanowires. J. Am. Chem. Soc. 2012, 134, 14423-14429. [CrossRef] [PubMed]

22. Shen, L.; Yang, S.-W.; Ng, M.-F.; Ligatchev, V.; Zhou, L.; Feng, Y. Charge-Transfer-Based Mechanism for Half-Metallicity and Ferromagnetism in One-Dimensional Organometallic Sandwich Molecular Wires. J. Am. Chem. Soc. 2008, 130, 13956-13960. [CrossRef] [PubMed]

23. Zhang, X.; Wang, J.; Gao, Y.; Zeng, X. Ab Initio Study of Structural and Magnetic Properties of $\mathrm{TM}_{n}(\text { ferrocene })_{n+1}(\mathrm{TM}=\mathrm{Sc}, \mathrm{Ti}, \mathrm{V}, \mathrm{Mn})$ Sandwich Clusters and Nanowires $(n=\infty)$. ACS Nano 2009, 3, 537-545. [CrossRef]

24. Fey, N. Organometallic molecular modelling-the computational chemistry of metallocenes: A review. J. Chem. Technol. Biotechnol. 1999, 74, 852-862. [CrossRef]

25. Coriani, S.; Haaland, A.; Helgaker, T.; Jørgensen, P. The Equilibrium Structure of Ferrocene. ChemPhysChem 2006, 7, 245-249. [CrossRef] [PubMed]

26. Aliabad, H.A.R.; Chahkandi, M. Comprehensive SPHYB and B3LYP-DFT Studies of Two Types of Ferrocene. Z. Anorg. Allg. Chem 2017, 643, 420-431. [CrossRef]

27. Xu, Z.-F.; Xie, Y.; Feng, W.-L.; Schaefer, H.F. Systematic Investigation of Electronic and Molecular Structures for the First Transition Metal Series Metallocenes $\mathrm{M}\left(\mathrm{C}_{5} \mathrm{H}_{5}\right)_{2}(\mathrm{M}=\mathrm{V}, \mathrm{Cr}, \mathrm{Mn}, \mathrm{Fe}, \mathrm{Co}$, and Ni). J. Phys. Chem. A 2003, 107, 2716-2729. [CrossRef]

28. Seller, P.; Duntitz, J.D. The Structure of Nickelocene at Room Temperature and at 101 K. Acta Cryst. 1980, 36, 2255-2260. [CrossRef]

29. Yu, M.; Antipin, R.B. Redetermination of the Cobaltocene Crystal Structure at $100 \mathrm{~K}$ and $297 \mathrm{~K}$ : Comparison with Ferrocene and Nickelocene. Struct. Chem. 1993, 4, 91-101.

30. Yu, M.; Antipin, R.B. Structure of Vanadocene in the Temperature Interval 108-357 K and the Nature of the Ring Disorder. Acta Cryst. 1996, 52, 314-322.

31. Robertson, R.E.; Mcconnell, H.M. The magnetic resonance properties of some sandwich compounds. J. Phys. Chem. 1960, 64, 70-77. [CrossRef]

32. Giannozzi, P.; Baroni, S.; Bonini, N.; Calandra, M.; Car, R.; Cavazzoni, C.; Ceresoli, D.; Chiarotti, G.L.; Cococcioni, M.; Dabo, I.; et al. QUANTUM ESPRESSO: A modular and open-source software project for quantum simulations of materials. J. Phys. Condens. Matter 2009, 21, 395502. [CrossRef] [PubMed]

33. Marzari, N.; Mostofi, A.A.; Yates, J.R.; Souza, I.; Vanderbilt, D. Maximally localized Wannier functions: Theory and applications. Rev. Mod. Phys. 2012, 84, 1419-1475. [CrossRef]

34. Rosenblum, M.; Fish, R.W. A convenient synthesis of some haloferrocenes. J. Org. Chem. 1965, 30, $1253-1254$.

35. Bernhartzeder, S.; Sunkel, K. Coordination chemistry of perhalogenated cyclopentadienes and alkynes. Part 30. New high-yield syntheses of monochloroferrocene and 1,2,3,4,5-pentachloroferrocene. Molecular structures of 1,2-dichloroferrocene and 1,2,3-trichloroferrocene. J. Organomet. Chem. 2012, 716, 146-149. [CrossRef]

36. Sunkel, K.; Bernhartzeder, S. Coordination chemistry of perhalogenated cyclopentadienes and alkynes. XXVIII [1] new high-yield synthesis of monobromoferrocene and simplified procedure for the synthesis of pentabromoferrocene. Molecular structures of 1,2,3-tribromoferrocene and 1,2,3,4,5-pentabromoferrocene. J. Organomet. Chem. 2011, 696, 1536-1540.

37. Sünkel, K. Coordination chemistry of pentahalocyclopentadienyls. Chem. Ber. -Recl. 1997, 130, 1721-1730.

38. Hnetinka, C.A.; Hunter, A.D.; Zeller, M.; Lesley, M.J.G. 1,1'-Dibromoferrocene. Acta Cryst. E 2004, 60, m1806-m1807. [CrossRef]

39. Romanov, A.S.; Mulroy, J.M.; Khrustalev, V.N.; Antipin, M.Y.; Timofeeva, T.V. Monohalogenated ferrocenes $\mathrm{C}_{5} \mathrm{H}_{5} \mathrm{FeC}_{5} \mathrm{H}_{4} \mathrm{X}(\mathrm{X}=\mathrm{Cl}, \mathrm{Br}$ and $\mathrm{I})$ and a second polymorph of $\mathrm{C}_{5} \mathrm{H}_{5} \mathrm{FeC}_{5} \mathrm{H}_{4} \mathrm{I}$. Acta Cryst. C 2009, 65, m426-m430. [CrossRef] 
40. Chaudret, B.; Jalon, F.A. Facile preparation of $\pi$-arene complexes of ruthenium $\left[\left(\eta^{5}-C_{5} M_{5}\right) R u(A r e n e)\right] X$ including a $\pi$-pyridine and the first $\pi$-furan derivatives. J. Chem. Soc. Chem. Commun. 1988, 711-713. [CrossRef]

41. Da, H.; Jin, H.M.; Lim, K.H.; Ligatchev, V.; Ng, M.-F.; Khoo, K.H.; Yang, S.-W. Half metal semiconductor reversible switch in bimetallic sandwich molecular wire via redox reactions. Nano Energy 2012, 1, $297-302$. [CrossRef]

42. Gardner, A.B.; Howard, J.; Waddington, T.C. The dynamics of ring rotation in ferrocene, nickelocene and ruthenocene by incoherent quasi-elastic neutron scattering. Chem. Phys. 1981, 57, 453-460. [CrossRef]

43. Brock, C.P.; Fu, Y. Rigid-Body Disorder Models for the High-Temperature Phase of Ferrocene. Acta Cryst. 1997, 928-938. [CrossRef]

44. Clec'h, G.; Calvarin, G. Etude Structurale Des Phases Desordonnees De $\mathrm{Co}\left(\mathrm{C}_{5} \mathrm{H}_{5}\right)_{2}, \mathrm{Mg}\left(\mathrm{C}_{5} \mathrm{H}_{5}\right)_{2}$, Et Transitions De Phases De $\left.\left(\mathrm{C}_{4} \mathrm{H}_{4}\right) \mathrm{N}\right) \mathrm{Fe}\left(\mathrm{C}_{5} \mathrm{H}_{5}\right)$. Mol. Cryst. Liq. Cryst. 2011, 128, 305-320. [CrossRef]

45. Chhor, K.; Pommier, C. Low temperature thermodynamic study of the stable and metastable phases of $\left(\mathrm{C}_{4} \mathrm{H}_{4} \mathrm{~N}\right) \mathrm{Fe}\left(\mathrm{C}_{5} \mathrm{H}_{5}\right)$. J. Chem. Thermodyn. 1984, 16, 503-517. [CrossRef]

46. Gregory, J.K.; Clary, D.C.; Liu, K.; Brown, M.G.; Saykally, R.J. The Water Dipole Moment in Water Clusters. Science. 1997, 275, 814-817. [CrossRef] [PubMed]

47. Silvestrelli, P.L.; Parrinello, M. Water Molecule Dipole in the Gas and in the Liquid Phase. Phys. Rev. Lett. 1999, 82, 3308-3311. [CrossRef]

48. Shieh, J.; Yeh, J.H.; Shu, Y.C.; Yen, J.H. Hysteresis behaviors of barium titanate single crystals based on the operation of multiple $90^{\circ}$ switching systems. Mater. Sci. Eng. B 2009, 161, 50-54. [CrossRef]

49. Grimme, S. Semiempirical GGA-type density functional constructed with a long-range dispersion correction. J. Comput. Chem. 2006, 27, 1787-1799. [CrossRef]

50. Sabatini, R.; Gorni, T.; de Gironcoli, S. Nonlocal van der Waals density functional made simple and efficient. Phys. Rev. B. 2013, 87, 4. [CrossRef]

51. Vydrov, O.A.; Van Voorhis, T. Nonlocal van der Waals density functional: The simpler the better. J. Chem. Phys. 2010, 133, 10. [CrossRef] [PubMed]

52. Thonhauser, T.; Zuluaga, S.; Arter, C.A.; Berland, K.; Schroder, E.; Hyldgaard, P. Spin Signature of Nonlocal Correlation Binding in Metal-Organic Frameworks. Phys. Rev. Lett. 2015, 115, 136402. [CrossRef] [PubMed]

53. Thonhauser, T.; Cooper, V.R.; Li, S.; Puzder, A.; Hyldgaard, P.; Langreth, D.C. Van der Waals density functional: Self-consistent potential and the nature of the van der Waals bond. Phys. Rev. B 2007, 76, 11. [CrossRef]

54. Langreth, D.C.; Dion, M.; Rydberg, H.; Schröder, E.; Hyldgaard, P.; Lundqvist, B.I. Van der Waals density functional theory with applications. Int. J. Quantum Chem. 2005, 101, 599-610. [CrossRef]

55. Murray, E.D.; Lee, K.; Langreth, D.C. Investigation of Exchange Energy Density Functional Accuracy for Interacting Molecules. J. Chem. Theory Comput. 2009, 5, 2754-2762. [CrossRef] [PubMed]

56. Lee, K.; Murray, E.D.; Kong, L.; Lundquist, B.I.; Langreth, D.C. Higher-accuracy van der Waals density functional. Phys. Rev. B. 2010, 82, 081101(R). [CrossRef]

57. Perdew, J.P.; Burke, K.; Ernzerhof, M. Generalized Gradient Approximation Made Simple. Phys. Rev. Lett. 1996, 77, 3865. [CrossRef] [PubMed]

58. Garrity, K.F.; Bennett, J.W.; Rabe, K.M.; Vanderbilt, D. Pseudopotentials for high-throughput DFT calculations. Comput. Mater. Sci. 2014, 81, 446-452. [CrossRef]

(C) 2019 by the authors. Licensee MDPI, Basel, Switzerland. This article is an open access article distributed under the terms and conditions of the Creative Commons Attribution (CC BY) license (http://creativecommons.org/licenses/by/4.0/). 